\title{
The Role of Participative Decision Making and Psychological Ownership in Enhancing Organizational Commitment and Knowledge Sharing Behavior
}

\author{
A Widanto and A Satrya \\ Department of Management, Faculty of Economic and Business, Universitas Indonesia, Jl. \\ Prof. Dr. Sumitro Djojohadikusumo 16424, Indonesia \\ 1amcawp@gmail.com
}

\begin{abstract}
The world is facing 4th industrial revolution, where technology improve very quickly, and make human resource being valuable asset. It makes organization should consider mechanism that enhancing human capital improvement. The purpose of this paper is to find the impact of participation in decision making as the mechanism and psychological ownership on organizational commitment which can lead to employee knowledge sharing. The purpose of this paper is to find the impact of participation in decision making and psychological ownership on organizational commitment which can lead to employee knowledge sharing. The survey involved 153 respondents from various industries. The results showed that participative decision making will strengthen employee's commitment through the assistance of psychological ownership. However, they did not show any influence on knowledge sharing behavior.
\end{abstract}

Keywords: Participative Decision Making, Psychological Ownership, Knowledge Sharing Behavior

\section{INTRODUCTION}

Many organizations are implementing technology in their activity to simplify the job. To compete, each organization must innovate to improve their performance. Innovation can be created from accumulating knowledge within the members of the organization [1]. It means human resources are important in developing the organization by creating a new product as well as an innovative idea. Thus, organization should consider various mechanisms to develop those assets to improve organizations.

Employee's chance to participate in organization's decision making (PDM) indicates good enterprise. Participative decision making rooted in "theory $\mathrm{Y}$ " perspective of management suggesting that employees are fundamentally interested in performing well at work and will be more attached and committed to a work organization if managers value employee contributions in making decisions that affect the nature of work [2]. Higher levels of Participative Decision- making have been found to be positively related to higher levels of organizational commitment, lower turnover, and higher employee productivity, also lead to better labor-management relations, stronger employee attachment to organizations, better quality decisions, and improved productivity. One of Participative Decisionmaking impact is Organizational Commitment (OC).

This study tries to elaborate the impact of Participative Decision Making to organizational commitment. In the following section, this study reviewing the past research that concern about these 
topics, and the relationship between them. We then review the impact of Participative Decision making to Organizational Commitment to find the relationship and the impact using Psychological Ownership as mediator variable.

\section{LITERATURE REVIEW}

\subsection{Participative Decision Making (PDM)}

\subsection{Participative Decision Making (PDM)}

Participative Decision Making is a signal that employees are valued by their employer [3]. Participative Decision making provides employees' direct or indirect voice in decisions and a chance to influence others in different levels of the organization [4].

There are six dimensions in Participative Decision making [5], that is rationale, structure, form, decision issues, degree of involvement, decision process. Participative Decision making also have categories (3), that is 1) direct employee participation with management in making work-related decisions, 2) consultative participation where employee opinions are considered by managers inmaking decisions, 3) employee partial ownership of the organization, and 4) representative participation through a union or staff association.

\subsection{Psychological Ownership}

Psychological Ownership (PO) is the sense of belonging, feel as though an object, an entity, or a thought is 'My Own' or 'Ours' [6]. Sense of belonging have a relation with attitude, self concept, and responsibility. Attitude Research finds that people will judge an idea and object better when having a sense of belonging to the target [7], Psychological Ownership drive someone to making positive attitude toward some entity [8]; Self Concept Psychologically, sense of belonging causing a person to see a tangible or intangible object as part of himself [9], [10]; Responsibility possession and responsibility create some responsibility toward some entity [6]. Possession causes an individual to protect and defend their property, including developing and limiting the access of others.

Psychological ownership came up to satisfied human motives, either genetic, or other social motives. The possessions shape consciousness, self-awareness, and perception of the world [11]. They also mentioned that Psychological Ownership can be found in three main motives 1). Efficacy and effectance; 2). Self-identify; and 3). Having place.

\subsection{Organizational Commitment}

Organizational Commitment (OC) is a psychological attachment of individuals feel to the organization [12]. Organizational Commitment make the member of the organization ask themselves about 'Should I stay in the organizational? Why should I do that?' those who have a strong commitment, have a desire to continue their affiliation with the organization. Affective commitment is an emotional bond to the organization (based on positive appeal and sense of belonging) [13].

Organizational Commitment consist of three components [14], affective, normative, and continuance. Affective Commitment is a feeling or a sense of belonging and a sense of attachment to the organization and related to personal character, organizational structure, and work experience. For example, wages, supervision, role clarity, and variation of ability [15]; 
Normative Commit me nt Generated by the experience of socialization that emphasizes the loyalty of employers because of a sense of duty to give repayment to them [14]; Continuance Commitment reflect the related costs as impact if leaving the company. It is the worker's sense of duty to persist in the organization based on their belief of "good things" to do [16].

\subsection{Knowledge Sharing}

Knowledge Sharing (KS), refers to a distribution of information or work-related knowledge to help and collaborate with fellow members and solve a problem [17][18]. The sharing of such knowledge can be done directly orally, indirectly through other media, or forwarding information from others [17][18]. Knowledge Sharing is the desire of an individual member within an organization to share their knowledge to other members of the organization [19]. In sharing his knowledge, an individual will expect an advantage to be gained by giving his knowledge, because in doing so one will surely expend participation cost like effort and time organization [19]. Knowledge sharing is done in the presence of a certain motive and is believed not to be done without the existence of a 'sacrifice'. There is a belief that expects a reciprocity gained when members do so organization [19].

\section{RESEARCH MODEL AND HYPOTHESIS}

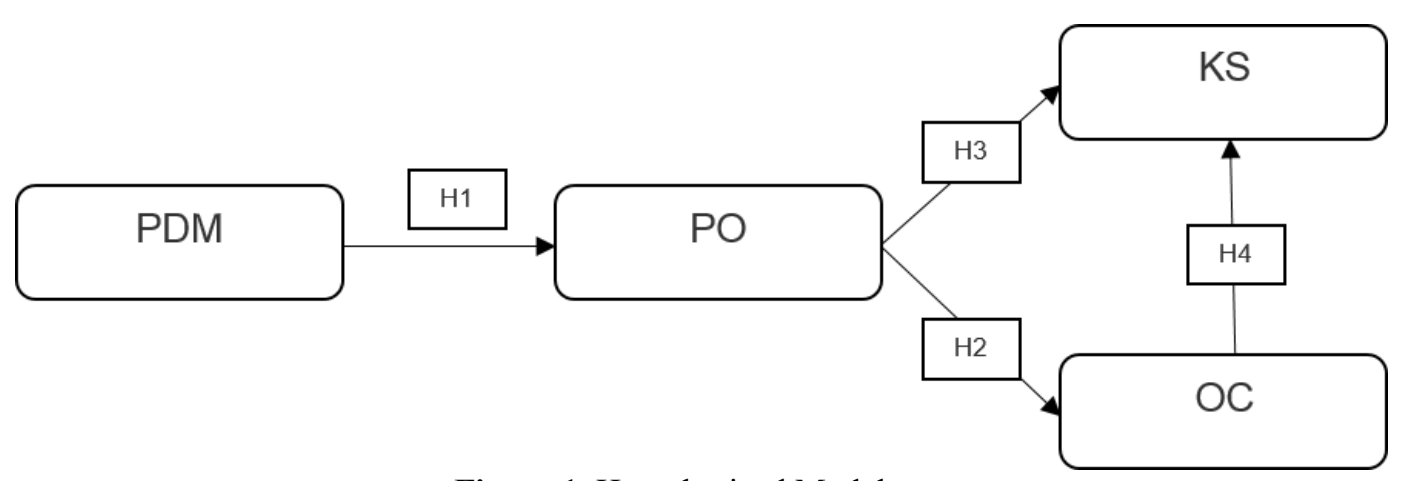

Figure 1. Hypothesized Model.

The conceptual of the research method adapted from [20]. This study tries to explore the relationships among Participative Decision Making, psychological ownership, organizational commitment and knowledge-sharing behavior. Hypotheses are proposed according to the propositions.

\subsection{Participative Decision Making and Psychological Ownership}

Participative decision making will satisfy the needs of human growth as self-actualization and fulfillment. This mechanism also increase their motivation to contributing with positive attitude, thus Participative Decision making mechanism will drive the member doing good to the organization [20]. Members who have a control over the organization feel they have the organization, thus generating psychological ownership through the participation, also make they feel controlling the organization and invest themselves in organization [11]. Higher the members participation in decision making, the higher their altruistic spirit that will resulting psychological Ownership level [21]. Consistently, 
workers who can participate in decision-making will create a sense of belonging that make them feel at home at the organization and willing to accept responsibilities that will improve the efficiency of organization [22].

Hypothesis 1: there is a positive relationship between Participative Decision making and

Psychological Ownership

\subsection{Psychological Ownership and Organizational Commitment}

Organizational Commitment is the attitude of a worker to an organization in which it identifies the organization's goals and devotes itself to the organization, in order to survive in the organization [23]. Organizational Commitment focuses on the worker's desire to stay in organization as a member [21]. While the Psychological Ownership emphasizes the ownership of the company by the workers. Mastery of an object creates a sense of belonging, in which the Psychological Ownership will satisfy the desire to have a worker. This has an impact as the greater the sense of belonging to the worker, the higher the willingness of the worker to stay in the company and more committed to the organization.

Hypothesis 2: there is a positive relationship between Psychological Ownership and Organizational Commitment

\subsection{Psychological Ownership, Organizational commitment, and Knowledge sharing}

The sharing of knowledge among workers will contribute to the creation and utilization of knowledge, then it will be an important role in organizational knowledge management. When organizations adopt appropriate mechanisms, such sharing of knowledge will have a major impact on the development of knowledge, and the most important knowledge to share is knowledge of knowhow and can be an important source of inimitable competitive advantage [20]. Organizations that apply high technology, need new ideas, innovations, information, new knowledge, then sharing knowledge related to these things will certainly help the organization in innovating [24].

Organizations can adopt mechanisms such as Participative Decision making that can encourage members' commitment to the organization and create a reciprocal relation between the organization and members that enhancing organizational efficiency [22]. Members' commitment to the organization is positively related to psychological ownership [21] which can enhance altruistic spirit and impact on extra-role behaviors such as knowledge sharing [25]. Members with a sense of belonging to the organization will demonstrate an altruistic spirit that becomes crucial in fostering knowledge sharing behavior [20], [21].

Hypothesis 3: There is a positive relationship between Psychological Ownership and Knowledge Sharing

When members are committed to the organization, they will produce an altruistic spirit which generates a positive attitude such as knowledge sharing [25]. In other words, the commitment to the organization is an antecedent that increases the altruistic spirit of the members which is an important component in creating positive member behaviors for the organization, in which case members with high altruistic zeal tend to be willing to share their knowledge [20].

Hypothesis 4: There is a positive relationship between Organizational Commitment and Knowledge Sharing Behavior on members. 


\section{METHOD}

This used data collected via online questionnaire that distributed randomly. Before distributing the questionnaires, pre-test involved 37 participants to inspect measurements validity and reliability. The main test was distributed to 400 employees from various industries and companies in Indonesia. Of the 400 questionnaires distributed, 250 questionnaires were returned and 153 were valid. Regarding the respondents' characteristics: $54 \%$ were male, and $46 \%$ were female; whereas $3 \%$ were Baby boomers, $4 \%$ were Gen X, 91\% were Millennials, and 2\% were Gen Z.

The measurement to asses Participative Decision Making adapted from Ruh, White, \& Wood [26] using five items included 'In general how much your influence on how you perform your job?' 'To what extent are you able to decide how to do your job?' 'In general, how much your influence on what goes on in your work group?', 'In general, how much your influence on deciding things which affect your job?' 'My superiors listen to my ideas and suggestion' ( $1=$ strongly disagree, 5=strongly agree). The Cronbach's $\alpha$ for this scale was 0.935

The measurement to asses Psychological Ownership adapted from Pierce, et al. [27]. Measurement items included, 'I feel this company is belong to me', 'I'm involved in the success or failure of the company', and 'I am willing to treat my company as my home'. A five-point Likert scale was used to assess these items ( $1=$ strongly disagree, $5=$ strongly agree). The Cronbach's $\alpha$ for this scale was 0.812

The measurement to asses Organizational Commitment adapted from Mowday et al. [28]. Measurement items included 'I am proud of being a company's member', 'I am highly concerned with my company's future', and 'I usual y tel my friends that my company is an ideal working place'. A five-point Likert scale was used to assess these items ( $1=$ strongly disagree, $5=$ strongly agree). The Cronbach's $\alpha$ for this scale was 0.839

The measurement to asses Knowledge Sharing adapted from Bartol \& Srivastava [29]. Measurement items included, 'I usual y share work-related know-how and information with my colleagues oral y or via the Internet', 'I usual y automatically share my work-related creativity with my colleagues', and 'I usual y help my colleagues to solve their work-related problems'. A five- point Likert scale was used to assess the items ( $1=$ strongly disagree, $5=$ strongly agree). The Cronbach's a for the scale was 0.694 .

\section{RESULT AND DISCUSSION}

\subsection{Structural model}

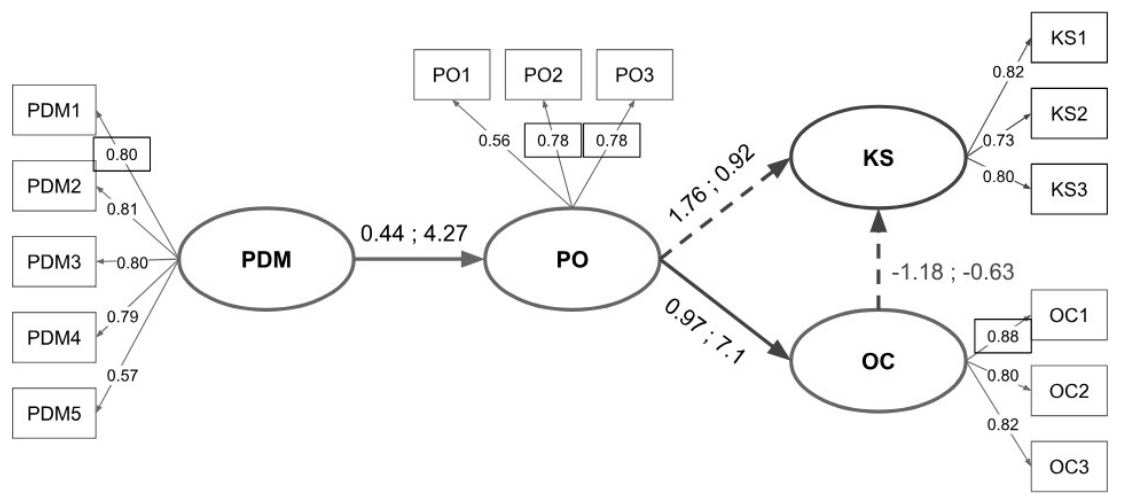

Figure2. Structural Model. 
This study used a structural model to test all hypothesis. Overall, the structural model provided an adequate fit to the data.

Table 1. Statistic Fit and Stability

\begin{tabular}{|c|c|c|c|}
\hline GOF Standards & Match Level & GO F Value & Fitness \\
\hline Goodness of Fit Index (GFI) & $\begin{array}{l}\text { GFI } \geq 0,90 \text { good fit; } 0,80 \leq \mathrm{GFI}< \\
0,90 \text { marginal fit }\end{array}$ & 0.88 & $\begin{array}{l}\text { Marginal } \\
\text { Fit }\end{array}$ \\
\hline $\begin{array}{l}\text { Root Mean Square Error of } \\
\text { Approximation (RMSEA) }\end{array}$ & $\begin{array}{l}\text { RMSEA } \leq 0,08 \text { good fit; RMSEA }< \\
0,05 \text { close fit }\end{array}$ & 0.078 & Good Fit \\
\hline $\begin{array}{l}\text { Adjusted Goodness of Fit Index } \\
\text { (AGFI) }\end{array}$ & $\begin{array}{l}\text { AGFI } \geq 0.90 \text { good fit, } 0.80 \leq \text { AGFI } \leq \\
0.90 \text { marginal } \\
\text { fit }\end{array}$ & 0.83 & $\begin{array}{l}\text { Marginal } \\
\text { Fit }\end{array}$ \\
\hline Norm ed Fit Index (NNFI) & $\begin{array}{l}\text { NFI } \geq 0.90 \text { good fit, } 0.80 \leq \mathrm{NFI} \leq \\
0.90 \text { marginal fit }\end{array}$ & 0.93 & Good Fit \\
\hline Non-Norm ed Fit Index (NNFI) & $\begin{array}{l}\text { NNFI } \geq 0.90 \text { good fit, } 0.80 \leq \mathrm{NNFI} \leq \\
0.90 \text { marginal } \\
\text { fit }\end{array}$ & 0.96 & Good Fit \\
\hline Relative Fit Index (RFI) & $\begin{array}{l}\text { RFI } \geq 0.90 \text { good fit, } 0.80 \leq \mathrm{RFI} \leq \\
0.90 \text { marginal fit }\end{array}$ & 0.92 & Good Fit \\
\hline Incremental Fit Index (IFI) & $\begin{array}{l}\text { IFI } \geq 0.90 \text { good fit, } 0.80 \leq \text { IFI } \leq 0.90 \\
\text { marginal fit }\end{array}$ & 0.96 & Good Fit \\
\hline Comparative Fit Index (CFI) & $\begin{array}{l}\mathrm{CFI} \geq 0.90 \text { good fit, } 0.80 \leq \mathrm{CFI} \leq \\
0.90 \text { marginal fit }\end{array}$ & 0.96 & Good Fit \\
\hline
\end{tabular}

Based on the model, the Participative Decision-Making variable has a positively related to Psychological Ownership thus supporting Hypothesis 1 (H1). The study found that participation in decision making has a positive effect on psychological ownership. This is evidenced from the T-Value is worth 4.27 ( $>$ 1.645). Refer to Standardized Factor Loading (SFL) on the model, the variable indicator of Participative Decision Making with the highest value is in the PDM2 indicator which states the freedom of the members in determining the way to do the work. While the largest SFL on Psychological Ownership variables are PO2 and PO3 that both show the value of 0.78 is a sense of member involvement in the success or failure experienced by this company / organization (PO2). At PO3, the member feels this company / organization is the 'second house'. The results mean when members are given the freedom in determining how to do a job, the member will feel involved in the success and failure of the organization and consider the organization as a second home for him. Thus, when an organization gives members freedom in determining how it works, members will feel involved in the failure and success of the company and will consider the organization to be second homes to them.

Significant results are also seen between the relationship of Psychological ownership with Organizational Commitment also proves Hypothesis 2 (H2). T-Value of both variables shows the number $7.10(>1,645)$ which means there is a positive relationship between the two variables. The largest SFL on Psychological Ownership variables are PO2 and PO3 which equally show the value of 0.78 that is the sense of member involvement in the success or failure experienced by this company / organization and the members feel this company / organization is their 'second house'. While the strongest indicator in the Organizational Commitment variable is $\mathrm{OC} 1$ to indicates the pride of a member would be the part of the company / organization.

The relationship between Psychological Ownership with Knowledge Sharing have T-value 0.52 or less than 1.645 that indicating these variables have no significant relationship. The relationship between Organizational Commitment with Knowledge Sharing are not significant the relationship 
between Organizational Commitment and Variable Knowledge Sharing is not significant. This is evidenced by the T-value of -0.63 where the value is below 1.645 . These results indicating Hypothesis 3 and Hypothesis 4 not proven.

\subsection{Implication and Suggestion}

In each variable, there is an indicator that achieves the highest value. The highest value indicator is PDM2 in Participative Decision Making, PO2 and PO3 variables on Psychological ownership variable, and $\mathrm{OC} 1$ on Organizational Commitment variable. Based on these indicators, it will be concluded that when a member was given the freedom in determining the way he does the work, the member will engage in the achievement of the organization and regards the organization as 'second house', and it will create a pride for him to become a part of the organization.

Significant relationship seen in the relationship between Participative Decision Making and Psychological Ownership that affect Knowledge Sharing. This significant relationship shows that the more members can participate in organizational decision making the higher the sense of ownership of the psychological members of the organization. If the management wants to grow a sense of belonging to the members of the organization, then increase the level of member participation in organizational decision making can be the one thing that can be done by management. Participation of members in decision-making can be realized by giving the freedom for members to determine how to complete the job. When that freedom is granted, a sense of ownership arises in the sense of involvement of members in the achievement of the organization and the members who treat the organization as a second house.

While the relationship of Psychological Ownership to Knowledge Sharing which also shows a significant positive relationship between them. With this positive relationship, the higher the sense of ownership of the psychological members of the organization, the higher the commitment of the member to the organization. The sense of ownership arises in the sense of involvement of members in the achievement of the organization and the members who treat the organization as a home for the two halves will create a sense of pride for members to be part of the organization.

Based on the model, there is no significant correlation between the Psychological Ownership to Knowledge Sharing, nor is there any significant relationship between Organizational Commitment to Knowledge Sharing, so there's no variables that can create the Knowledge Sharing behavior. This indicates research model has not been able to answer how to encourage knowledge sharing behavior that can encourage the creation of new ideas and innovations. This will certainly be an important thing to think about considering the economic and technological developments require business actors to continue to be able to innovate to continue, to compete, and survive.

\section{CONCLUSION}

Participative Decision Making positively related to Psychological Ownership which Positively related to Organizational Commitment, although the relation between Organizational Commitment and Knowledge Sharing, also Psychological Ownership and Knowledge Sharing are not significant. This result proving Organizational Commitment and Psychological Ownership have not encourage Knowledge Sharing behavior. Next research needs to consider about adding mediator to enhancing Knowledge Sharing behavior that encourage the creation of innovation in organization. 


\section{REFERENCES}

[1] R. Kamacsak and F. Bulutlar, "The influence of knowledge sharing on innovation," Eur. Bus. Rev., vol. 22, no. 3, pp. 306-317, 2010.

[2] P. G. Northouse, Leadership: Theory and Practice. Thousand Oaks, CA: Sage Publications, 1997.

[3] J. Elele and D. Fields, "Participative decision making and organizational commitment," Cross Cult. Manag. An Int. J., vol. 17, no. 4, pp. 368-392, 2010.

[4] J. L. Cotton, D. A. Vollrath, K. L. Froggatt, M. L. Lengnick-Hall, and K. R. Jennings, "Employee Participation: Diverse Forms and Different Outcomes," Acad. Manag. Rev., vol. 13, no. 1, p. 8, Jan. 1988.

[5] J. S. Black and H. B. Gregersen, "Participative Decision-Making: An Integration of Multiple Dimensions," Hum. Relations, vol. 50, no. 7, pp. 859-878, Jul. 1997.

[6] L. Furby, "Possession in humans: An exploratory study of its meaning and motivation Social Behavior and Personality," Soc. Behav. Personal. an Int. J., vol. 6, no. 1, pp. 4965, Jan. 1978.

[7] J. K. Beggan, "On the social nature of nonsocial perception: The mere ownership effect," J. Pers. Soc. Psychol., vol. 62, no. 2, pp. 229-237, 1992.

[8] J. M. Nuttin, "Affective consequences of mere ownership: The name letter effect in twelve European languages,” Eur. J. Soc. Psychol., vol. 17, no. 4, pp. 381-402, 1987.

[9] R. W. Belk, "Possessions and the Extended Self," J. Consum. Res., vol. 15, no. 2, p. 139, Sep. 1988.

[10] H. Dittmar, The social psychology of material possessions : to have is to be. Upper Saddle River, New Jersey: Prentice Hall, 1992.

[11] J. L. Pierce, T. Kostova, and K. T. Dirks, "Toward a Theory of Psychological Ownership in Organizations," Acad. Manag. Rev., vol. 26, no. 2, pp. 298-310, Apr. 2001.

[12] C. A. O'Reil and J. Chatman, "Organizational commitment and psychological attachment: The effects of compliance, identification, and internalization on prosocial behavior.," J. Appl. Psychol., vol. 71, no. 3, pp. 492-499, 1986.

[13] J. Meyer and N. J. Allen, Commitment in the workplace: Theory, Research, and Application. Thousand Oaks, CA: SAGE Publications, Inc., 1997.

[14] J. P. Meyer, N. J. Allen, and C. A. Smith, "Commitment to organizations and occupations: Extension and test of a three-component conceptualization.," J. Appl. Psychol., vol. 78, no. 4, pp. 538-551, 1993.

[15] L. C. Hartmann and M. Bambacas, "Organizational commitment: A multi method scale analysis and test of effects," Int. J. Organ. Anal., vol. 8, no. 1, pp. 89-108, Jan. 2000.

[16] H. S. Becker, "Notes on the Concept of Commitment," Am. J. Sociol., vol. 66, no. 1, pp. 32-40, Jul. 1960.

[17] J. N. Cummings, "Work Groups, Structural Diversity, and Knowledge Sharing in a Global Organization," Manage. Sci., vol. 50, no. 3, pp. 352-364, Mar. 2004.

[18] S. E. Jackson, A. DeNisi, and M. A. Hitt, Managing knowledge for sustained competitive advantage: Designing strategies for effective human resource management. San Fransisco: Joey-Bass, 2003.

[19] M. Gibbert and H. Krause, "Practice exchange in a best practice marketplace," in Knowledge management case book: Siemens best practices, T. H. Davenport and G. J. B. Probst, Eds. Erlangen: Publicis Corporate Publishing, 2002, pp. 89-105.

[20] T.-S. Han, H.-H. Chiang, and A. Chang, "Employee participation in decision making, 
psychological ownership and knowledge sharing: mediating role of organizational commitment in Taiwanese high-tech organizations," Int. J. Hum. Resour. Manag., vol. 21, no. 12, pp. 2218-2233, 2010.

[21] L. Van Dyne and J. L. Pierce, "Psychological ownership and feelings of possession: three field studies predicting employee attitudes and organizational citizenship behavior," J. Organ. Behav., vol. 25, no. 4, pp. 439-459, Apr. 2004.

[22] A. Wilkinson, "Empowerment: theory and practice," Pers. Rev., vol. 27, no. 1, pp. 4056, Feb. 1998.

[23] R. T. Mowday, R. M. Steers, and L. W. Porter, "The measurement of organizational commitment," J. Vocat. Behav., vol. 14, no. 2, pp. 224-247, Apr. 1979.

[24] J. Darroch and R. McNaughton, "Examining the link between knowledge management practices and types of innovation," J. Intellect. Cap., vol. 3, no. 3, pp. 210-222, Sep. 2002.

[25] P. Podsakoff, "Organizational citizenship behaviors: a critical review of the theoretical and empirical literature and suggestions for future research," J. Manage., vol. 26, no. 3, pp. 513-563, 2000.

[26] R. A. Ruh, J. K. White, and R. R. Wood, "Job Involvement, Values, Personal Background, Participation in Decision Making, and Job Attitudes," Acad. Manag. J., vol. 18, no. 2, pp. 300-312, Jun. 1975.

[27] M. P. O'driscoll, J. L. Pierce, and A.-M. Coghlan, "The Psychology of Ownership," Gr. Organ. Manag., vol. 31, no. 3, pp. 388-416, Jun. 2006.

[28] R. T. Mowday, R. M. Steers, and L. W. Porter, "The measurement of organizational commitment," J. Vocat. Behav., vol. 14, no. 2, pp. 224-247, Apr. 1979.

[29] K. M. Bartol and A. Srivastava, "Encouraging Knowledge Sharing: The Role of Organizational Reward Systems," J. Leadersh. Organ. Stud., vol. 9, no. 1, pp. 64-76, Aug. 2002. 